\title{
Designing Website-Based Scholarship Management Application for Teaching of Analytical Hierarchy Process (AHP) in Decision Support Systems (DSS) Subjects
}

\author{
https://doi.org/ 10.3991/ijim.v15i09.23513 \\ Elfi Tasrif ${ }^{(凶)}$, Hadi Kurnia Saputra, Denny Kurniadi, \\ Hendra Hidayat, Akrimullah Mubai \\ Universitas Negeri Padang, Padang, Indonesia \\ elfitasrifeft.unp.ac.id
}

\begin{abstract}
Teaching Analytical Hierarchy Process (AHP) in Decision Support Systems (DSS) subjects encourages students to know how a good decision is taken. AHP itself in the field of education and teaching has been widely used as an effective and efficient method in solving educational problems. The purpose of this paper is to designing website-based scholarship management application for teaching of analytical hierarchy process (ahp) in decision support systems (dss) subjects. Scholarship management using AHP is choosing the right criteria is very important. This system uses 5 criteria, namely academic value, academic achievement, non-academic achievement, parents 'income, and parents' dependents, as a basis for producing decision-supporting information. The scholarship management system is embodied in a website-based computer application. Utilizing this application provides more assistance to donors, so that the results of this learning are not only proven in theory but also in practice in real conditions. In addition, the Website-Based Scholarship Management Application can be run on a mobile basis and can be accessed wherever and whenever they are.
\end{abstract}

Keywords-Scholarship, Website Based Application, Teaching Analytical Hierarchy Process, Decision Support System.

\section{$1 \quad$ Introduction}

Decision making is a difficult task. This task has a significant impact on these decision makers [1]. These impacts can be in the form of good or bad impacts, according to the accuracy in choosing the time, atmosphere, place and the decision itself. This is because every decision has consequences [2,3]. The emergence of these consequences is influenced by various factors in the decision-making process. This factor gives consideration to decision makers, and it often makes them uncertain in making these decisions [4]. For this reason, there are many ways to help decision makers in making decisions, including the use of Decision Support Systems [5, 6].

Decision Support Systems (DSS) is a tool that can assist decision makers in providing recommendation information that runs on a computer application $[7,8]$. As 
in the field of education in research [9], in selecting outstanding students, then in the health sector in research [10], in helping to make decisions on the number of biomarkers and therapeutics in administering drugs to patients [11], then in the field of social as in research [12], in choosing employees to be promoted and more. Some of these studies show that DSS is used to help solve a semi-structured problem. Where this semi-structured problem occurs in a predictable or recurring time span, so the resolution procedure can be patterned using a method [13]. There are many types of methods used in DSS, such as the Analytic Hierarchy Process (AHP) method developed by Saaty [14].

The AHP method is a decision support system method that describes complex problems into several simpler levels of hierarchical problems, making them easier to analyze in the system being built $[15,14]$. The first level in the AHP method is the main objective of the DSS, then the second level is in the form of criteria, and the third level is in the form of candidates [15]. In the AHP method, the criteria level data will be used in comparing any information obtained from each candidate in realizing the main goal of helping decision making in solving a problem [16, 17].

The AHP method is very possible to be used for teaching learning in technical education [18], with the characteristics of technical education that requires competency and product-oriented learning [19]-[22], AHP teaching is an alternative solution, including in informatics engineering education in DSS subjects. There are many problem solving that DSS can help in everyday life. For example, the scholarship management problem is a semi-structured problem [23]. The problem of scholarship management occurs repeatedly, which with this iteration forms a pattern that can be processed by the DSS. Where the results of DSS processing can later help donors in choosing to whom to provide assistance [24]. For this reason, this paper will discuss AHP teaching in DSS subjects, with learning outcomes in the form of a website-based scholarship management application.

\section{Research Methods}

DSS subjects using the AHP method in scholarship management begins with determining criteria. These criteria are obtained from prospective scholarship recipients by setting their priority data. This is so that the information generated can help donors make decisions. The criteria used in this processing are presented in Figure 1.

In Figure 1, there are five data criteria for prospective scholarship recipients used. These five criteria are the basis for determining the priority order of scholarship recipients. These criteria consist of Academic Value (AV), Academic Achievement (AA), Non Academic Achievement (NAA), Parents' Income (PI) and Parents' Dependents (PD). Each criterion in the data for prospective scholarship recipients has a value based on the level of data the scholarship recipient has. The levels are presented in table 1. 


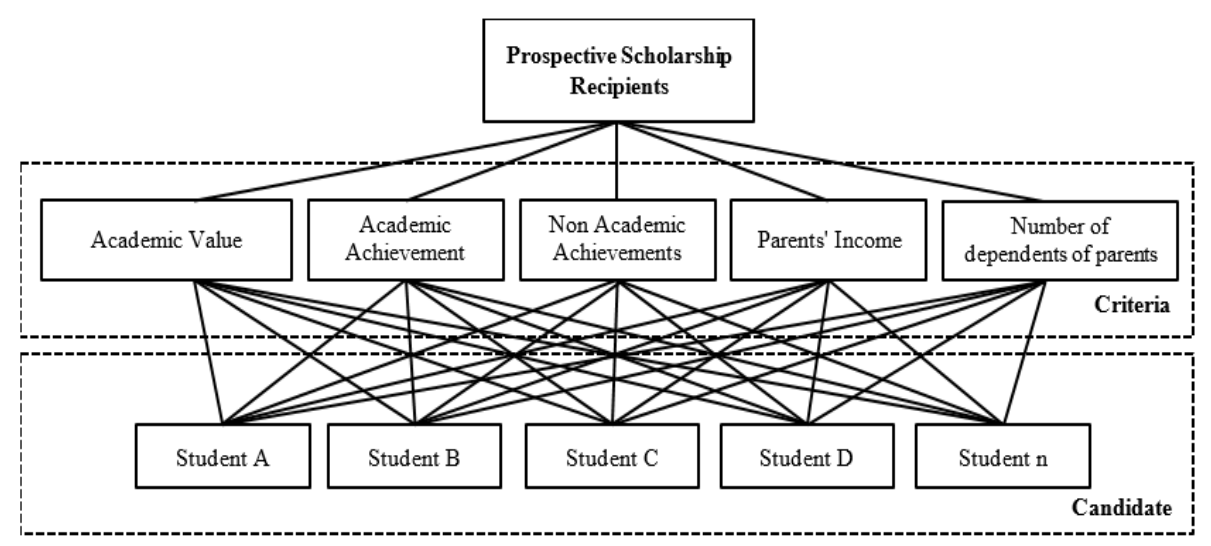

Fig. 1. Criteria for assessing potential donation recipients

Table 1. Value of Data Criteria

\begin{tabular}{|c|c|c|c|c|c|}
\hline Score & AV & AA & NAA & PI & PD \\
\hline Very Good & GPA $>3.75$ & International & International & PI $<=$ Rp. $1.500 .000,-$ & PD $>5$ \\
\hline Good & $3.5<\mathrm{GPA}<=3.75$ & National & National & $\begin{array}{c}\text { Rp. } 1.500 .000<\mathrm{PI}<=\mathrm{Rp} . \\
2.000 .000-\end{array}$ & $\mathrm{PD}=5$ \\
\hline Enough & $3.25<\mathrm{GPA}<=3.5$ & $\begin{array}{c}\text { Province } / \\
\text { City }\end{array}$ & $\begin{array}{c}\text { Province } / \\
\text { City }\end{array}$ & $\begin{array}{c}\text { Rp. } 2.000 .000<\mathrm{PI}<=\mathrm{Rp} . \\
2.500 .000,-\end{array}$ & $\mathrm{PD}=4$ \\
\hline Less & $3.00<\mathrm{GPA}<=3.25$ & College & College & $\begin{array}{c}\text { Rp. } 2.500 .000<\mathrm{PI}<=\mathrm{Rp} . \\
3.000 .000,-\end{array}$ & $\mathrm{PD}=3$ \\
\hline Very Less & $\mathrm{GPA}<3.00$ & There is no & There is no & PI $>$ Rp. 3.000.000,- & $\mathrm{PD}<=2$ \\
\hline
\end{tabular}

The data in table 1 provides information that each criterion set is based on the highest to the lowest values. The highest score will get the value of 'Very Good', followed by 'Good', 'Enough', 'Less' and the lowest is 'Very Less ' based on the achievement range of values on the predetermined criteria. Each criterion has its own value and priority, the values and priorities are in table 2 .

Table 2. Value and Criteria Priority

\begin{tabular}{|c|c|c|c|c|c|c|c|c|c|}
\hline Criteria & PI & PD & AV & AA & NAA & $\begin{array}{c}\text { Value } \\
\text { Criteria }\end{array}$ & $\begin{array}{c}\text { Priority } \\
\text { Vector }\end{array}$ & $\begin{array}{c}\text { Addition of } \\
\text { Each Line }\end{array}$ & $\begin{array}{c}\text { Consisten- } \\
\text { cy Ratio }\end{array}$ \\
\hline PI & 1 & 2 & 3 & 4 & 5 & 2,081 & 0,416 & 2,129 & 2,545 \\
\hline PD & 0,5 & 1 & 2 & 3 & 4 & 1,309 & 0,262 & 1,337 & 1,599 \\
\hline AV & 0,33 & 0,5 & 1 & 2 & 3 & 0,805 & 0,161 & 0,815 & 0,976 \\
\hline AA & 0,25 & 0,33 & 0,5 & 1 & 2 & 0,493 & 0,099 & 0,495 & 0,594 \\
\hline NAA & 0,2 & 0,25 & 0,33 & 0,5 & 1 & 0,312 & 0,062 & 0,314 & 0,376 \\
\hline Total & 2,28 & 4,08 & 6,83 & 10,5 & 15 & 5,00 & 1,00 & & 6,090 \\
\hline
\end{tabular}

Table 2 starts from the comparison between each criterion. A comparison using the Saaty scale, namely 1 to 9 to show a synthesis of priority [25]. As in the criterion PI 
with PD which has a ratio of 1 to 2, which means that PI is 2 times more prioritized than PD and so on. The explanation of this comparison value scale is described in table 3 . The calculation is continued to calculate the value of each criterion by formula (1). This value is intended to calculate the portion of the value of each criterion used with a maximum of five according to the number of criteria used.

The calculation is continued by calculating the value of the Priority Vector to find out the portion of the priority value for each criterion. The maximum number of all portions of the priority value is one, which is obtained from the calculation using the formula (2). The calculation is continued by adding up each criterion row with formula (3) and then calculating the consistency ratio for each line (partial) with formula (4). After obtaining the consistency ratio value partially, the calculation is continued to obtain the consistency ratio value simultaneously with formula (7).

$$
\begin{aligned}
& k=\sum\left(n / \sum n\right) \ldots \\
& P V=k / \sum k \\
& P S=\sum(n * P V) \\
& R K=P V+P S \\
& \lambda \max =\sum k+\sum R K \\
& \mathrm{CI}=\lambda \max +\sum k \\
& \mathrm{CR}=\mathrm{CI} / \mathrm{IR}
\end{aligned}
$$

Description

$$
\begin{aligned}
& \mathrm{k}=\text { Criteria } \quad \lambda \text { Max }=\text { Maximum Lamda } \\
& \mathrm{n}=\text { Value on the Criteria } \mathrm{CI}=\text { Consistency Index } \\
& \mathrm{PV}=\text { Priority Vector } \quad \mathrm{CR}=\text { Consistency Ratio } \\
& \mathrm{PS}=\text { Addition of Each Line IR = Index Random Consistency } \\
& \mathrm{RK}=\text { Consistency Ratio }
\end{aligned}
$$

Table 3. Saaty Comparison Scale

\begin{tabular}{|c|l|}
\hline Scale $\boldsymbol{a}_{i, j}$ & \multicolumn{1}{c|}{ Description } \\
\hline 1 & The two criteria are equally important. \\
\hline 3 & The criteria $i$, is somewhat (weak) more important than criteria $j$. \\
\hline 5 & The criteria $i$, is sufficiently (strongly) important than criteria $j$. \\
\hline 7 & The criteria $i$, is very (very strong) important than criteria $j$. \\
\hline 9 & The criteria $i$, has extreme importance (absolutely) from criteria $j$. \\
\hline $2,4,6,8$ & The criteria $i$, and $j$ have a mean value between two adjacent decision values. \\
\hline
\end{tabular}

Source: [25].

In the calculation using the formula (7), the final value obtained from the Consistency Ratio (CR) simultaneously is -0.85 with CI -0.945 and IR 1.12 . The CR value of -0.85 is smaller than $0.1(10 \%)$, which means that the $C R$ value in the ratio of the 
portion of each criterion used is consistent [26]. After the main criterion value is obtained, it is followed by the calculation of the sub-criterion value in the same way of calculating the main criterion value. The results of the calculations of the five main and sub-criteria are presented in table 4.

Table 4. Value of Main Criteria and Sub Criteria

\begin{tabular}{|c|c|c|c|c|c|}
\hline Criteria & AV & AA & NAA & PI & PD \\
\hline Value & 0.161 & 0.099 & 0.062 & 0.416 & 0.262 \\
\hline \multicolumn{7}{|c|}{ Value of Sub Criteria } \\
\hline Very Good & 1 & 1 & 1 & 1 & 1 \\
\hline Good & 0.509 & 0.694 & 0.545 & 0.604 & 0.471 \\
\hline Enough & 0.312 & 0.445 & 0.216 & 0.347 & 0.335 \\
\hline Less & 0.186 & 0.310 & 0.139 & 0.147 & 0.186 \\
\hline Very Less & 0.144 & 0.190 & 0.104 & 0.095 & 0.093 \\
\hline
\end{tabular}

In table 4, the sub-criterion value shows the portion of each main criterion, if compiled all the values of the sub-criteria will get a maximum value of $1(100 \%)$. In the main criteria, AV has a portion of the value $0.161(16.1 \%)$ of the total value, which if an AV data gets the sub-criteria 'Very Good' then it will get a value of 1 . The value 1 has a portion of the maximum value on AV's main criterion, namely $16.1 \%$. But if the AV sub-criteria are in the range of 'Good' to 'Very Less', then the value on AV will be multiplied by the value of the portion.

For example, if the data on the AV sub-criterion is 'enough', then the calculation is $0.161 \times 0.312=0.05$, which means that the value of AV is ' enough ', namely 0.05 $(5 \%)$ from a maximum of $16.1 \%$. Furthermore, the AA criteria had a portion of 0.099 $(9.9 \%)$. Followed by the NAA criteria which have a value portion of $0.062(6.2 \%)$, PI criteria which have a value portion of 0.416 (41.6\%), and PD criteria which have a value portion of $0.262(26.2 \%)$, which later on if the maximum value obtained from each criterion will get a value of $100 \%$. The value of the main criteria and sub-criteria will later become a reference in providing an assessment of the data of each prospective scholarship recipient which will then be sorted based on the highest score.

Ordering the value of prospective scholarship recipients is intended to assist donors in choosing to whom to channel their assistance. The performance process of the AHP method is described in a flowchart so that each process step in the system can be described clearly and in detail [27]. The process flowchart from the AHP method is presented in Figure 2.

The AHP method flowchart starts with students as Prospective Scholarship Recipients (CPB) data entry. After that the data is processed by the AHP method, starting from the definition of variables, namely the compilation of data $(z[])$ and (a) as parameters $(z[])$ starting from 0 . Followed by giving weights according to the Data Criteria Value (NKD) and Sub Value. Criteria (NSK) on CPB data. The results of the assessment are stored temporarily in the data compilation $(z[])$ and the value of variable a is added to 1 . When the CPB data is equal to 0 or does not exist anymore, the data is stored in the database (DB). However, if the CPB data is still there, the loop is 
repeated. The data stored in the DB are then presented in the form of priority order information to help donors. Data on DB is also given to CPB in the form of information on donations and donors.

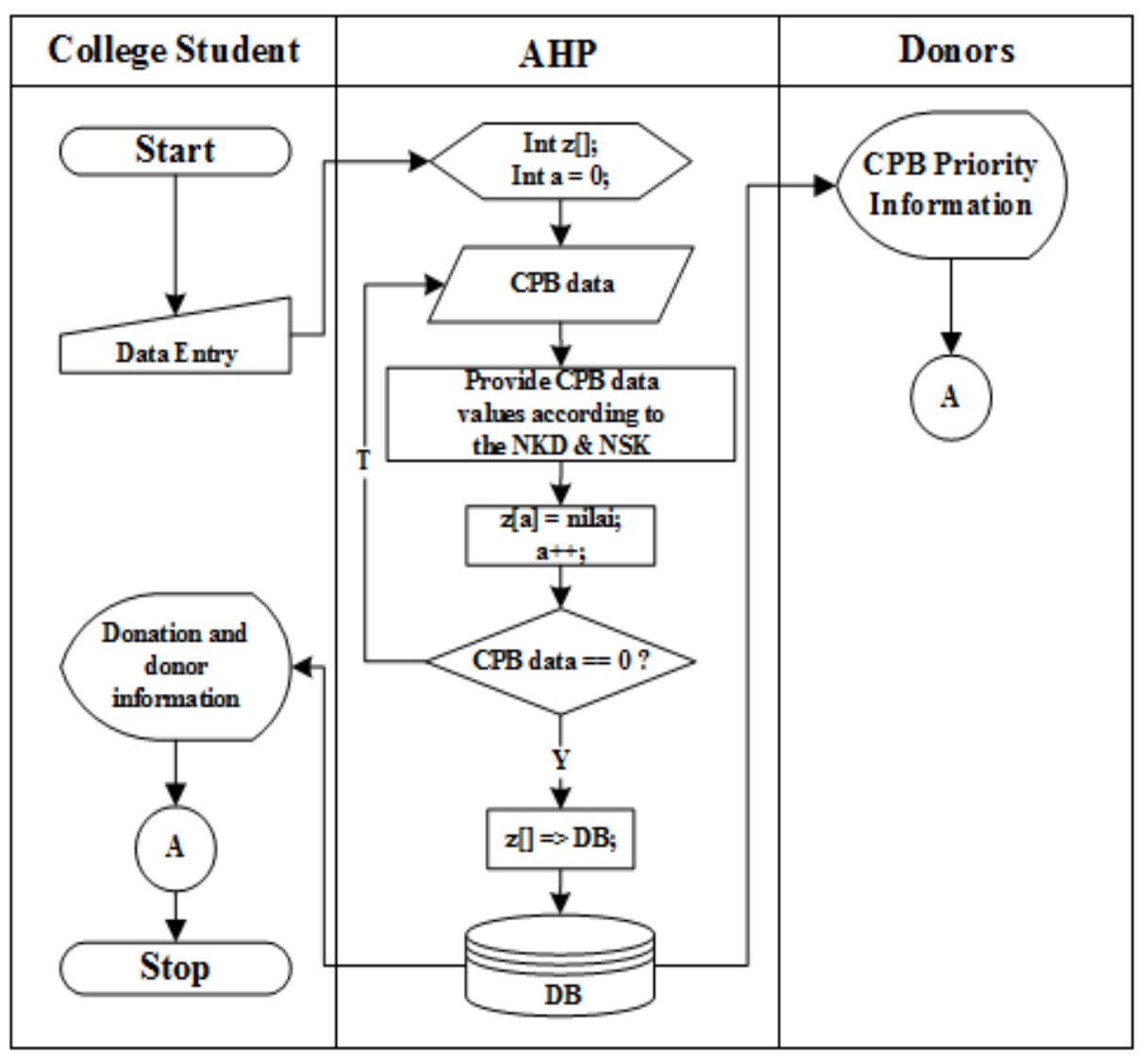

Fig. 2. AHP Method Flowchart

\section{Implementation and Results}

AHP learning outcomes in DSS subjects are implemented in a website-based scholarship management application. This scholarship management application is called the Foster Parents Electronic Application or abbreviated as e-ORA. The design of this e-ORA application uses the AHP method, in which the information generated aims to help donors. The results of this learning are presented in Figure 3. 


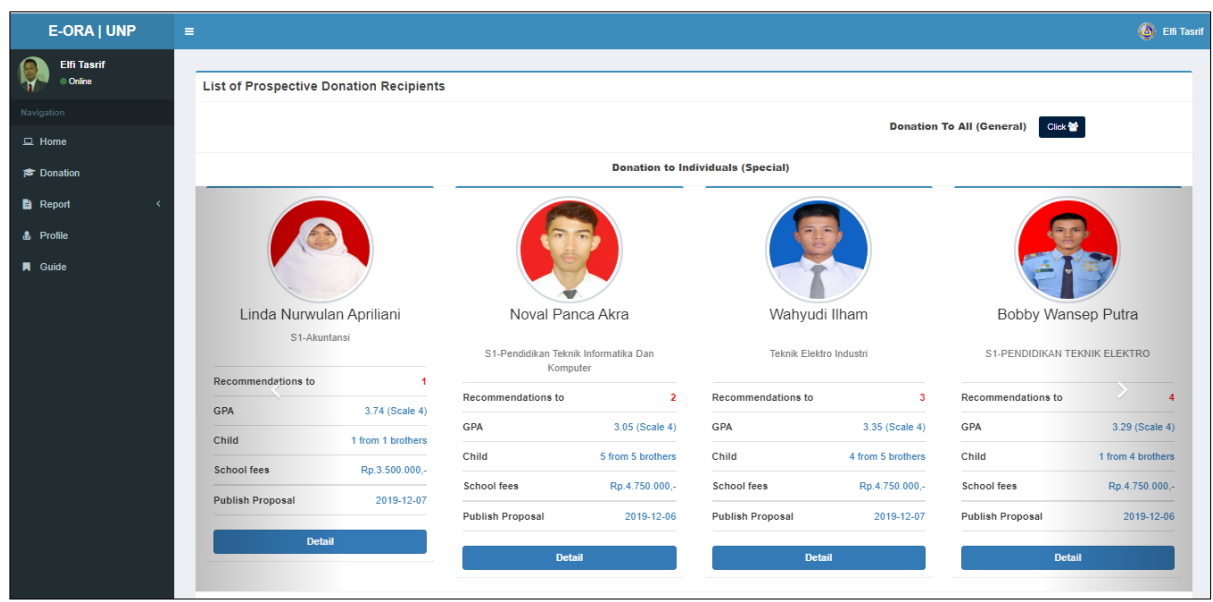

Fig. 3. Results of the implementation of the AHP method in the e-ORA application

The figure 3 shows the results of the implementation of the AHP method which produces information on the priority order of the CPB, namely students. The order of priority is presented from the first to the last priority which is equipped with student identity data. This priority is based on the data they have. Priority information will be intended to assist donors in choosing to whom to donate their assistance. Apart from the order of priority, further information is also provided to potential donors. The information is presented in Figure 4.

The figure 4 presents general student information. This information is in the form of the name, gender, date of birth, study program, semester, GPA, achievement, and evidence files to support this information. Meanwhile, student donor data will also be displayed. The display of donor data is presented in Figure 5.

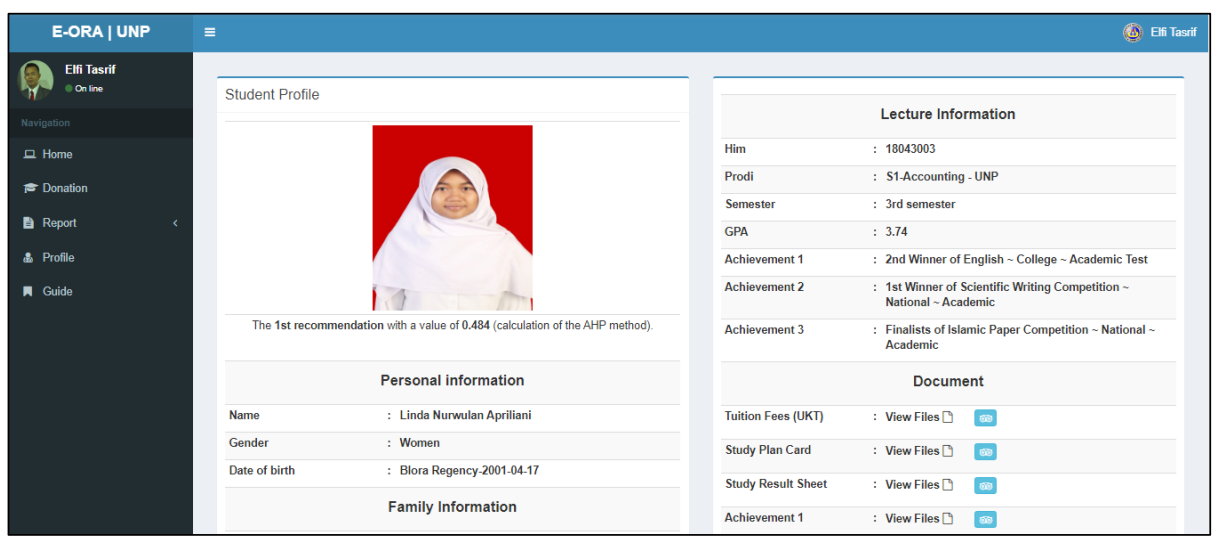

Fig. 4. Student Information 


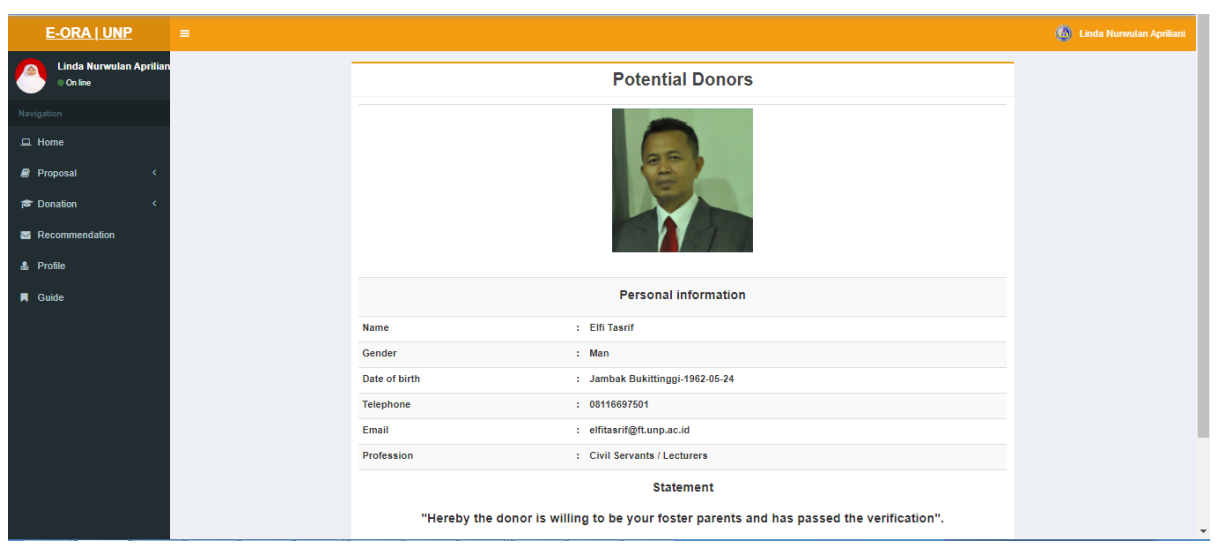

Fig. 5. Donor Information

On the donor information page, the information displayed is the name, gender, place, and date of birth, telephone number, email, occupation, and the donor's statement which contains a message that they are ready to give donations or scholarships to the student concerned. This information will appear to students if the donor agrees that their information is displayed to students otherwise, this information will not be displayed to students.

\section{Discussion}

AHP itself in education and teaching has been widely used as an effective and efficient method in solving educational problems [28]-[30]. AHP teaching in DSS subjects encourages students to know how a good decision is taken [31]. This knowledge is further developed by utilizing one of the DSS methods, namely AHP [22], in assisting decision making which is implemented in scholarship management. In scholarship management using AHP is choosing the right criteria is very important [32]. As in research scholarship using AHP [33], which uses several criteria, namely academic achievement, non-academic achievement, personality, mileage, report cards, organization, parent's dependents, parental income, and parental status in scholarship management. In research DSS for scholarship [34], in the selection of scholarship recipients using the criteria for majors, parental income, parental responsibility, academic achievement, student non-academic achievement.

In research [35], choosing the right scholarship recipients, they used the criteria for economic ability, academic achievement, organizational activeness, and student nonacademic achievement. For this reason, from several criteria that have been presented, 5 criteria are taken which are the basis for this AHP teaching. The criteria used are academic value, academic achievement, academic achievement, parents 'income, and the student's parents' dependents. The selection of these criteria is based on the assumption that these criteria can provide a distinguishing value for each student and can represent their condition accurately. Processing data from each criterion using 
AHP produces information that is then presented in a website-based computer application, which aims to be more effective $[36,37]$. So AHP learning in this learning, besides producing data calculation results $[38,39]$, also produces a product in the form of a scholarship management application that provides more value, this learning outcome is in line with the demands of learning in technical education [40], which is product-oriented has the commercial potential [41].

\section{Conclusion}

The challenges of learning in engineering education in the era of globalization of communication technology and the economy require students to be more active, think critically, think creatively, and collaborate. More concrete learning with case studies is needed nowadays. AHP learning in DSS subjects provides a different learning atmosphere. Students are not only taught in making the right decision but also able to make a system to support the decision making. So that this learning process helps shape student competencies in engineering education, including students in informatics engineering education. In addition, the products produced and manufactured using the AHP method for scholarship management have been successfully realized in a website-based computer application. Utilizing this application provides more assistance to donors so that the results of this learning are not only proven in theory but also in practice in real conditions.

\section{Acknowledgment}

Thanks to the Engineering Faculty of The Universitas Negeri Padang which has facilitated and contributed to conducting the research, the lecturers, and staff of the Engineering Faculty, the experts who contributed in giving suggestions during the research implementation. The research activities are also aided by various other departments for comments and information about how the process of teaching informatics engineering education. Furthermore, thanks to the staff and operators that facilitate the fieldwork.

\section{$7 \quad$ References}

[1] D. L. Martínez, S. Brusoni, "Cognitive flexibility and adaptive decision-making: Evidence from a laboratory study of expert decision makers," Strategic Management Journal., vol. 39, no. 4, pp. 1031-1058, 2018. https://doi.org/10.1002/smj.2774

[2] J. Kornack, A. L. Williams, K. A. Johnson, and E. M. Mendes, "Reopening the Doors to Center-Based ABA Services: Clinical and Safety Protocols During COVID-19," Behav. Anal. Pract., vol. 13, no. 3, pp. 543-549, 2020. https://doi.org/10.1007/s40617-02000462-7

[3] S. M. Mueller, J. Schiebener, G. Stöckigt, and M. Brand, "Short- and long-term consequences in decision-making under risk: immediate feedback about long-term prospects benefits people tending to impulsive processing," J. Cogn. Psychol., vol. 29, 
Paper-Designing Website-Based Scholarship Management Application for Teaching of Analytical...

no. 2, pp. 217-239, 2017. https://doi.org/10.1080/20445911.2016.1245660

[4] P. H. D. Santosa, S. M. Nevesa, D. O. Sant'Annab, C. H. d. Oliveira, H. D. Carvalhoc, "The analytic hierarchy process supporting decision making for sustainable development: An overview of applications," Journal of Cleaner Production., vol. 212, pp. 119-138, 2019. https://doi.org/10.1016/j.jclepro.2018.11.270

[5] N. Nurmalini and R. Rahim, "Study Approach of Simple Additive Weighting For Decision Support System,” no. April, pp. 1-5, 2017. https://doi.org/10.31227/osf.io/8sjvt

[6] Z. Zhai, J. F. Martínez, V. Beltran, and N. L. Martínez, "Decision support systems for agriculture 4.0: Survey and challenges," Comput. Electron. Agric., vol. 170, no. August 2019, p. 105256, 2020. https://doi.org/10.1016/j.compag.2020.105256

[7] M. F. Ali, A. A. Aziz, and S. H. Sulong, "The role of decision support systems in smallholder rubber production: Applications, limitations and future directions," Comput. Electron. Agric., vol. 173, no. April, p. 105442, 2020. https://doi.org/10.1016/j.compag. $\underline{2020.105442}$

[8] Lisnawita, F. C. Lucky Lhaura Van, Fajrizal, A. Zamsuri, and M. Syarawi, "Developing Decision Support System: Assessing the Lecturers' Performance with Additive Weighting Method," IOP Conf. Ser. Earth Environ. Sci., vol. 175, no. 1, 2018. https://doi.org/10.1088/1755-1315/175/1/012100

[9] A. Puspita, Y. Yuningsih, H. Amalia, and A. F. Lestari, "Implementation of Ahp Method in the Decision Support of Selection of Student Achievement Case Study: Senior High School," J. Ris. Inform., vol. 2, no. 2, pp. 91-100, 2020. https://doi.org/10.34288/ jiri.v2i2.131

[10] S. Walsh et al., "Decision Support Systems in Oncology review article abstract," Clin. Cancer Informatics, pp. 1-9, 2019. https://doi.org/10.1200/CCI.18.00001

[11] T. Nasiri, M. Bahadori, R. Ravangard, and M. Meskarpour Amiri, "Factors Affecting the Failure to Report Medical Errors by Nurses Using the Analytical Hierarchy Process (AHP)," Hosp. Top., vol. 98, no. 4, pp. 135-144, 2020. https://doi.org/10.1080/00185868. $\underline{2020.1796555}$

[12] D. Abdullah, H. Djanggih, S. Suendri, H. Cipta, and N. Nofriadi, "Fuzzy model tahani as decision support system for employee promotion,” Int. J. Eng. Technol., vol. 7, no. 2.5 Special Issue 5, pp. 88-91, 2018. https://doi.org/10.14419/ijet.v7i2.5.13958

[13] S. V. Zykov, IT Crisisology: Smart Crisis Management in Software Engineering, Springer, Singapore, 2021. https://doi.org/10.1007/978-981-33-4435-8

[14] T. L. Saaty, "A scaling method for priorities in hierarchical structures," J. Math. Psychol., vol. 15, no. 3, pp. 234-281, 1977. https://doi.org/10.1016/0022-2496(77)90033-5

[15] M. A. B. Promentilla, K. B. Aviso, R. I. G. Lucas, L. F. Razon, and R. R. Tan, "Teaching Analytic Hierarchy Process (AHP) in undergraduate chemical engineering courses," Educ. Chem. Eng., vol. 23, pp. 34-41, 2018. https://doi.org/10.1016/j.ece.2018.05.002

[16] S. Abadi et al., "Implementation of fuzzy analytical hierarchy process on notebook selection," Int. J. Eng. Technol., vol. 7, no. 2.27 Special Issue 27, pp. 238-243, 2018. https://doi.org/10.14419/ijet.v7i2.27.12047

[17] Z. D. U. Durmuşoğlu, "Assessment of techno-entrepreneurship projects by using Analytical Hierarchy Process (AHP)," Technology in Society., vol. 54, pp. 41-46, 2018. https://doi.org/10.1016/j.techsoc.2018.02.001

[18] V. Acharya, S. K. Sharma, S. K. Gupta, "Analyzing the factors in industrial automation using analytic hierarchy process," Computers and Electrical Engineering., vol. 71, no. 2, 2017. https://doi.org/10.1016/j.compeleceng.2017.08.015

[19] M. U. Isa and Y. Bin Kamin, "Effective Strategies for Integrating Project Based Learning into Woodwork Technology Education and Understanding at Tertiary Institutes in 
Paper-Designing Website-Based Scholarship Management Application for Teaching of Analytical...

Nigeria," Int. J. Emerg. Technol. Learn., vol. 14, no. 20, pp. 120-136, 2019. https://doi.org/10.3991/ijet.v14i20.11468

[20] H. Hidayat, B. Y. Tamin, S. Herawati, Z. Ardi, and A. P. Muji, "The Contribution of Internal Locus of Control and Self-Concept to Career Maturity in Engineering Education," Int. J. Adv. Sci. Eng. Inf. Technol., vol. 10, no. 6, pp. 2282-2289, 2020. https://doi.org/10.18517/ijaseit.10.6.11698

[21] T. I. Anisimova, F. M. Sabirova, and O. V. Shatunova, "Formation of design and research competencies in future teachers in the framework of STEAM education," Int. J. Emerg. Technol. Learn., vol. 15, no. 2, pp. 204-217, 2020. https://doi.org/10.3991/ijet.v15i02. 11537

[22] X. Zhang, S. Wang, Y. Cao, and G. Chen, "Application of analytical hierarchy process in teaching quality analysis of english writing," Int. J. Emerg. Technol. Learn., vol. 15, no. 14, pp. 137-150, 2020. https://doi.org/10.3991/ijet.v15i14.15359

[23] T. D. Puspitasari, E. O. Sari, P. Destarianto, H. Y. Riskiawan, "Decision Support System for Determining Scholarship Selection using an Analytical Hierarchy Process," J. Phys. Conf. Ser., vol. 953, no. 2, pp. 1-5, 2018. https://doi.org/10.1088/1742$\underline{6596 / 953 / 1 / 012119}$

[24] E. Tasrif, M. H. Prasyah, D. Kurniadi, H.K. Saputra, A. Mubai, T. Y. Pahtoni, "Sistem Pendukung Keputusan Aplikasi Electronic-Orang Tua Asuh Menggunakan Metode Simple Additive Weighting," J. Vocat. Tek. Elektron. dan Inform., vol. 8, no. 4, pp. 8693, 2020. http://ejournal.unp.ac.id/index.php/voteknika/article/view/110219

[25] Š. Kudláč, V. Štefancová, and J. Majerčák, "Using the Saaty Method and the FMEA Method for Evaluation of Constraints in Logistics Chain," Procedia Eng., vol. 187, pp. 749-755, 2017. https://doi.org/10.1016/j.proeng.2017.04.433

[26] A. S. Baswaraj, M. Sreenivasa Rao, and P. J. Pawar, "Application of AHP for process parameter selection and consistency verification in secondary steel manufacturing," Mater. Today Proc., vol. 5, no. 13, pp. 27166-27170, 2018. https://doi.org/10.1016/j.matpr.2018.09.027

[27] E. Tasrif, A. Huda, H. K. Saputra, and A. Mubai, "Design of Server Performance Monitoring Application Integrated Administration Service System in Electronic Engineering Department," J. Phys. Conf. Ser., vol. 1387, no. 1, 2019. https://doi.org/10.1088/1742-6596/1387/1/012029

[28] H. Chaibate, A. Hadek, S. Ajana, and S. Bakkali, "Analytical Hierarchy Process Applied to Pedagogical Method Selection Problems," Educ. Res. Int., vol. 2021, no. Lc, 2021. https://doi.org/10.1155/2021/6664758

[29] G. Andrew, "Metrics and methodologies for measuring teaching quality in higher education: developing the Teaching Excellence Framework (TEF)," Educational Review., vol. 70, no. 2, pp. 129-148, 2018. https://doi.org/10.1080/00131911.2017.1410106

[30] N. Sael, T. Hamim, and F. Benabbou, "Implementation of the Analytic Hierarchy Process for student profile analysis," Int. J. Emerg. Technol. Learn., vol. 14, no. 15, pp. 78-93, 2019. https://doi.org/10.3991/ijet.v14i15.10779

[31] M. ŞAHIN and H. YURDUGÜL, "A Content Analysis Study on the Use of Analytic Hierarchy Process in Educational Studies," Eğitimde ve Psikolojide Ölçme ve Değerlendirme Derg., vol. 9, no. 4, pp. 376-392, 2018. https://doi.org/10.21031/epod. $\underline{373784}$

[32] R. Latief and L. Lefen, "Analysis of Chinese government scholarship for international students using Analytical Hierarchy Process (AHP)," Sustain., vol. 10, no. 7, 2018. https://doi.org/10.3390/su10072112

[33] R. Mawarni and M. Parida, "Website Implementation for Making Scholarship 
Paper-Designing Website-Based Scholarship Management Application for Teaching of Analytical...

Acceptance Decisions At Smk N 1 Talangpadang Using the Analytical Hieararchy Process Method," Int. J. Inf. Syst. Comput. Sci., pp. 113-122, 2019. https://core.ac.uk/download/pdf/276535301.pdf

[34] E. Sugiyarti, K. A. Jasmi, B. Basiron, M. Huda, K. Shankar, and A. Maseleno, "Decision support system of scholarship grantee selection using data mining," Int. J. Pure Appl. Math., vol. 119, no. 15, 2018. https://doi.org/10.5772/47788

[35] P. Napitupulu and A. Surbakti, "Design of Decision Support System Providing Scholarship with Analytical Hierarchy Process (AHP) Method on Yayasan Seri Amal St. Ignatius Medan,” J. Phys. Conf. Ser., vol. 1114, no. 1, 2018. https://doi.org/10.1088/ 1742-6596/1114/1/012089

[36] Q. N. Naveed, M. R. N. Qureshi, A. O. Alsayed, A. H. Muhammad, S. Sanober, and A. Shah, "Prioritizing barriers of E-Learning for effective teaching-learning using fuzzy analytic hierarchy process (FAHP)," 4th IEEE Int. Conf. Eng. Technol. Appl. Sci. ICETAS 2017, vol. 2018-January, pp. 1-8, 2018. https://doi.org/10.1109/ICETAS. 2017.8277855 .

[37] J. P. A. Runtuwene and I. R. H. T. Tangkawarow, "The quality classification of professional teacher using fuzzy-analytical hierarchy process," IOP Conf. Ser. Mater. Sci. Eng., vol. 830, no. 2, 2020. https://doi.org/10.1088/1757-899X/830/2/022099

[38] T. R. Sahroni and H. Ariff, "Design of analytical hierarchy process (AHP) for teaching and learning," Proc. - 11th 2016 Int. Conf. Knowledge, Inf. Creat. Support Syst. KICSS 2016, 2017. https://doi.org/10.1109/KICSS.2016.7951412

[39] E. Thanassoulis, P. K. Dey, K. Petridis, I. Goniadis, and A. C. Georgiou, "Evaluating higher education teaching performance using combined analytic hierarchy process and data envelopment analysis," J. Oper. Res. Soc., vol. 68, no. 4, pp. 431-445, 2017. https://doi.org/10.1057/s41274-016-0165-4

[40] Ganefri, H. Hidayat, I. Kusumaningrum, and A. Mardin, "Needs analysis of entrepreneurships pedagogy of technology and vocational education with production base learning approach in higher education," Int. J. Adv. Sci. Eng. Inf. Technol., vol. 7, no. 5, pp. 1701-1707, 2017. https://doi.org/10.18517/ijaseit.7.5.1510

[41] H. Hidayat, Z. Ardi, Yuliana, and S. Herawati, "Exploration of the need analysis for technopreneurship scientific learning models in higher vocational education," Int. J. Econ. Bus. Res., vol. 18, no. 3, pp. 356-368, 2019. https://doi.org/10.1504/IJEBR.2019. $\underline{102733}$

\section{Authors}

Elfi Tasrif, is a $\mathrm{PhD}$ in Vocational Education. He is a Senior Lecture in Department of Informatics Engineering Education, Engineering Faculty of Universitas Negeri Padang, Padang, Indonesia. His research areas include Vocational Education and Informatics Engineering Education.

Hadi Kurnia Saputra, He is a Lecturer in in Department of Informatics Engineering Education, Engineering Faculty of Universitas Negeri Padang, Padang, Indonesia. His research areas include Vocational Education, Information Technology, Computer Networks, and Data Mining.

Denny Kurniadi, He is a Senior Lecturer in in Department of Informatics Engineering Education, Engineering Faculty of Universitas Negeri Padang, Padang, Indonesia. His research areas include Vocational Education, and Information Technology. 
Paper-Designing Website-Based Scholarship Management Application for Teaching of Analytical...

Hendra Hidayat, $\mathrm{He}$ is a Lecturer in in Department of Electronics Engineering Education, Engineering Faculty of Universitas Negeri Padang, Padang, Indonesia. His research areas include Technical Vocational and Education Training, and Engineering Education.

Akrimullah Mubai, He is a Junior Lecturer in in Department of Informatics Engineering Education, Engineering Faculty of Universitas Negeri Padang, Padang, Indonesia. His research areas include Vocational Education, and Information Technology.

Article submitted 2021-04-25. Resubmitted 2021-04-30. Final acceptance 2021-04-30. Final version published as submitted by the authors. 